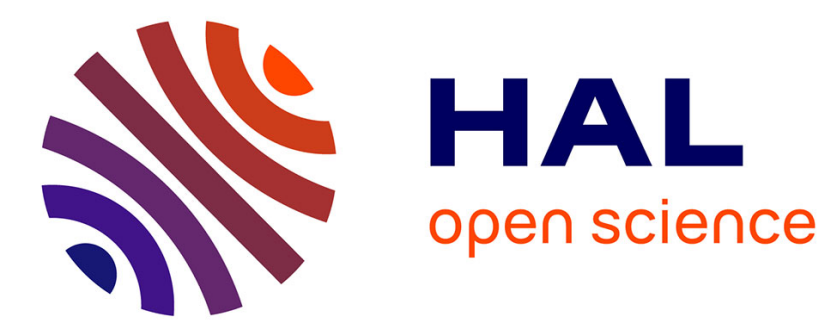

\title{
The origin of Antarctic precipitation: a modelling approach
}

Gilles Delaygue, Valerie Masson, Jean Jouzel, Randal Koster, Richard Healy

\section{To cite this version:}

Gilles Delaygue, Valerie Masson, Jean Jouzel, Randal Koster, Richard Healy. The origin of Antarctic precipitation: a modelling approach. Tellus B - Chemical and Physical Meteorology, 2000, 52 (1), pp.19-36. 10.3402/tellusb.v52i1.16079 . hal-03101961

\section{HAL Id: hal-03101961 \\ https://hal.science/hal-03101961}

Submitted on 21 Jun 2021

HAL is a multi-disciplinary open access archive for the deposit and dissemination of scientific research documents, whether they are published or not. The documents may come from teaching and research institutions in France or abroad, or from public or private research centers.
L'archive ouverte pluridisciplinaire HAL, est destinée au dépôt et à la diffusion de documents scientifiques de niveau recherche, publiés ou non, émanant des établissements d'enseignement et de recherche français ou étrangers, des laboratoires publics ou privés. 


\section{Tellus B: Chemical and Physical Meteorology}

\section{The origin of Antarctic precipitation: a modelling approach}

\section{Gilles Delaygue, Valérie Masson, Jean Jouzel, Randal D. Koster \& Richard J. Healy}

To cite this article: Gilles Delaygue, Valérie Masson, Jean Jouzel, Randal D. Koster \& Richard J. Healy (2000) The origin of Antarctic precipitation: a modelling approach, Tellus B: Chemical and Physical Meteorology, 52:1, 19-36, DOI: 10.3402/tellusb.v52i1.16079

To link to this article: https://doi.org/10.3402/tellusb.v52i1.16079

\section{(c) 2000 The Author(s). Published by Taylor \& Francis.}

\section{曲 Published online: 15 Dec 2016.}

Submit your article to this journal $₫$

\section{山 Article views: 65}

\section{Q View related articles $₫$}

Citing articles: 6 View citing articles 


\title{
The origin of Antarctic precipitation: a modelling approach
}

\author{
By GILLES DELAYGUE ${ }^{1 *}$, VALÉRIE MASSON ${ }^{1}$, JEAN JOUZEL $^{1}$, RANDAL D. KOSTER $^{2}$ and \\ RICHARD J. HEALY ${ }^{3},{ }^{1}$ Laboratoire des Sciences du Climat et de l'Environnement (LSCE), Orme des \\ Merisiers, CEA Saclay, 91191 Gif-sur-Yvette Cedex, France, ${ }^{2}$ Hydrological Sciences Branch, Laboratory \\ for Hydrospheric Processes, Code 974, NASA/Goddard Space Flight Center, Greenbelt, MD 20771, USA, \\ ${ }^{3}$ Marine Chemistry \& Geochemistry MS 25, Woods Hole Oceanographic Institution, Woods Hole, \\ MA 02543, USA
}

\begin{abstract}
The contribution of different moisture sources to Antarctic precipitation for present-day and glacial conditions is estimated with the NASA/GISS Atmospheric General Circulation Model. Despite its low horizontal resolution $\left(8^{\circ} \times 10^{\circ}\right)$, this model simulates reasonably well the broad features of the observed present-day hydrological cycle. Simulated present-day Antarctic precipitation is dominated throughout the year by moisture from a subtropical/midlatitude band $\left(30^{\circ} \mathrm{S}-60^{\circ} \mathrm{S}\right)$. The moisture supplied to a given coastal area of Antarctica originates mostly in the adjacent oceanic basin; closer to the pole, other oceanic basins can also contribute significantly. Replacing the present-day sea surface temperatures (SSTs) and sea ice cover in the GCM with those from the CLIMAP oceanic reconstruction for the last glacial maximum (LGM), greatly increases the simulated latitudinal temperature gradient, with the consequence of slightly enhancing the contribution of low latitude moisture to Antarctic precipitation. It also changes the seasonality of the different contributions and thus their budget, particularly in coastal regions. Because the nature of LGM tropical SSTs is still under debate, we performed an additional LGM simulation in which the tropical SSTs are reduced relative to those of CLIMAP. The resulting decrease in the latitudinal gradient brings the relative contributions to Antarctic precipitation more in line with those of the present-day simulation.
\end{abstract}

\section{Introduction}

The Antarctic ice sheet, the largest surficial freshwater reservoir on the Earth $\left(\sim 30 \cdot 10^{6} \mathrm{~km}^{3}\right)$, is an important component of the climate system. Fluctuations of the hydrological cycle may induce changes in the ice sheet mass balance, with potentially important consequences for sea level change on short and long timescales (a sea level increase of about $70 \mathrm{~m}$ would result from a total melt) (Warrick et al., 1996). Moreover, the Antarctic ice sheet constitutes a unique archive of past climate

\footnotetext{
* Corresponding author.

Additional affiliation: Centre Européen de Recherche et d'Enseignement en Géoscience de l'Environnement (CEREGE), Europôle de l'Arbois BP 80, 13545 Aix-enProvence Cedex 4, France.
}

and environmental changes, with ice core records now extending through the last four climatic cycles (Petit et al., 1997), roughly 400000 years. Fig. 1 shows the various Antarctic sites where deep drillings have already been achieved (Byrd, Dome C, Dome B, Vostok and few coastal sites), or is ongoing or planned (Dome Fuji, Siple Dome, Dome $\mathrm{C}$ and Dronning Maud Land; these last two drillings are undertaken under the framework of EPICA, the European Project for Ice Coring in Antarctica).

The reconstruction of past Antarctic climate is largely based on the interpretation of the oxygen $18\left(\delta^{18} \mathrm{O}\right)$ or deuterium $(\delta \mathrm{D})$ profiles measured along these ice cores (Lorius et al., 1979; Jouzel et al., 1996). An empirical relationship between isotope concentration in precipitation and local 


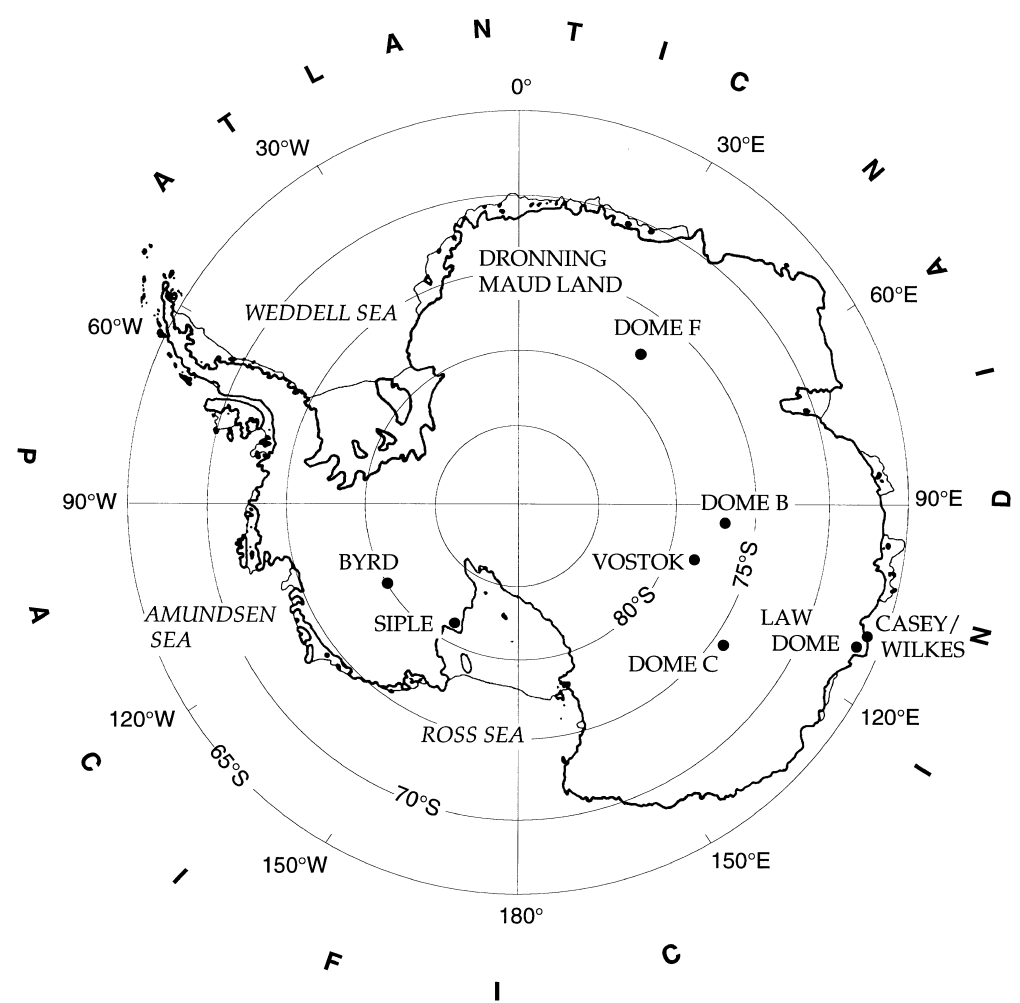

Fig. 1. The Antarctic ice core drilling sites and regions discussed in the text. Dome C stands for Dome Concordia, Dome F for Dome Fuji.

temperature has been established from presentday measurements; this relationship has been used to interpret the isotope paleodata in the ice cores in terms of past temperatures. The implicit assumption in this approach is that the measured present-day spatial relationship holds at a single location through time. This assumption is now being challenged by alternative estimates of glacial to interglacial temperature changes inferred from borehole thermometry for Greenland (Cuffey et al., 1995; Johnsen et al., 1995) and to a lesser degree for Antarctica (Salamatin et al., 1998).

Indeed, the assumption requires close scrutiny because the isotopic content of polar precipitation depends not only on the local temperature, but also on the origin and transport history of the precipitating water (Koster et al., 1992). Thus, if the origin of precipitation changes in time, the temporal isotope-temperature relationship may differ from the present-day spatial relationship. Temporal changes in precipitation seasonality and vertical atmospheric structure may also lead to disagreement in the temporal and spatial relationships (see Jouzel et al. (1997), for a recent review), but Krinner et al. (1997a) have shown them to have little effect.

A better understanding of the moisture sources for Antarctic precipitation - and how the relative contributions of these sources may have varied with time - would presumably improve the interpretation of the Antarctic ice core data. Unfortunately, moisture contributions from different evaporative sources cannot be isolated through direct measurement. One common indirect approach is based on the relationship between evaporative source conditions (temperature, humidity, wind speed) and deuterium excess $(d=$ $\delta D-8 \cdot \delta^{18} \mathrm{O}$ ) at the precipitation site. Petit et al. (1991) and Ciais et al. (1995) applied a Rayleightype isotopic model, which captures this relationship well, to Antarctic surface snow measurements and inferred a major subtropical evaporative 
source. They could not discount, however, an additional contribution from nearby coastal waters. More recently, using the same model, Delmotte (1997) suggested a seasonal variation in the relative strengths of the sources contributing to precipitation at the Law Dome site on the East Antarctic coast. Other studies concerning Antarctic precipitation origins, based on hydrological and isotopic approaches, give divergent conclusions (see Bromwich (1988) for a review). Since then, an analysis of storm tracks across the southern hemisphere (Jones and Simmonds, 1993) has imposed new constraints on vapour origin, at least in a longitudinal sense.

These indirect approaches generally assume an idealized moisture history (precipitation and mixing) along the trajectory from ocean to ice sheet. A more realistic representation of the moisture history can be obtained with an atmospheric general circulation model (AGCM) fitted with special tracer diagnostics. With such a model, moisture evaporating from a specified source region can be "tagged", and this tracer vapour can be followed through the atmosphere until it precipitates. Examination of the tracer precipitation diagnostics at a given site establishes the evaporative sources for the precipitation there, as simulated by the AGCM (Joussaume et al., 1986; Koster et al., 1986).

Using this approach, Koster et al. (1992) established the sources of Antarctic precipitation for present-day July conditions. They found that the average source temperature for July precipitation in Antarctica is roughly $12^{\circ} \mathrm{C}$. Here, we extend this analysis to the full annual cycle and to both present-day and ice age conditions in order to quantify the potential seasonal and climatic variations in the relative strengths of the moisture sources for Antarctic precipitation.

\section{Tracing water with an AGCM}

\subsection{The GISS atmospheric general circulation model}

For the present study, we use the Model II version of the NASA Goddard Institute for Space Studies (GISS) atmospheric GCM (Hansen et al., 1983). The boundary conditions forcing the atmosphere dynamics include diurnally-varying and seasonally-varying insolation, seasonally-varying sea surface temperature and sea ice distribution, and atmospheric composition $\left(\mathrm{CO}_{2}\right.$ content, etc.). Each grid box is divided into fractions of open sea, sea ice, land and continental ice, which are treated independently. Several studies have shown that this GCM, even when run at a coarse $\left(8^{\circ} \times 10^{\circ}\right)$ resolution, successfully reproduces the main features of the earth's climate system, due in part to detailed treatments of physical processes (Hansen et al., 1984). Our simulations use the $8^{\circ} \times 10^{\circ}$ resolution, with nine $\sigma$-levels in the vertical. We discuss in Section 3, the simulated hydrological characteristics around Antarctica.

\subsection{Use of the tracer version of the GISS AGCM}

Tracer diagnostics have been incorporated into the GISS AGCM to track the water evaporating from specified source regions as it is transported through the atmosphere (Koster et al., 1988). This is achieved by applying the same model physics to the tagged tracer water as to the model's standard water prognostic variables. This tracer model has also been used to transport water isotopes (Jouzel et al., 1987), using appropriate fractionation physics at each change of water phase. The resulting fields of isotope concentration in precipitation agree well with observed fields, lending some support to the simulated hydrological cycle.

One potential problem in the application of the tracer model to the determination of Antarctic moisture sources involves the singularity at the south pole grid point in the GCM cylindrical coordinate system, since atmospheric transports across the pole is poorly represented. The very low temperature at the pole itself, however, reduces the air vapour content to half that at surrounding cells on average, so that any transport across the pole would, in any case, be small.

In the present experiment, because the northern hemisphere's contribution to high southern latitude precipitation is found negligible (less than $1 \%$, as determined from a similar simulation in which the northern hemisphere was marked as a single tracer), our evaporative moisture sources are defined only in the southern hemisphere. We first used basin geography to group the southern hemisphere's oceanic grid cells into the three basin-specific oceanic source regions shown in Fig. 2a. All nonpolar cells that contain more than 

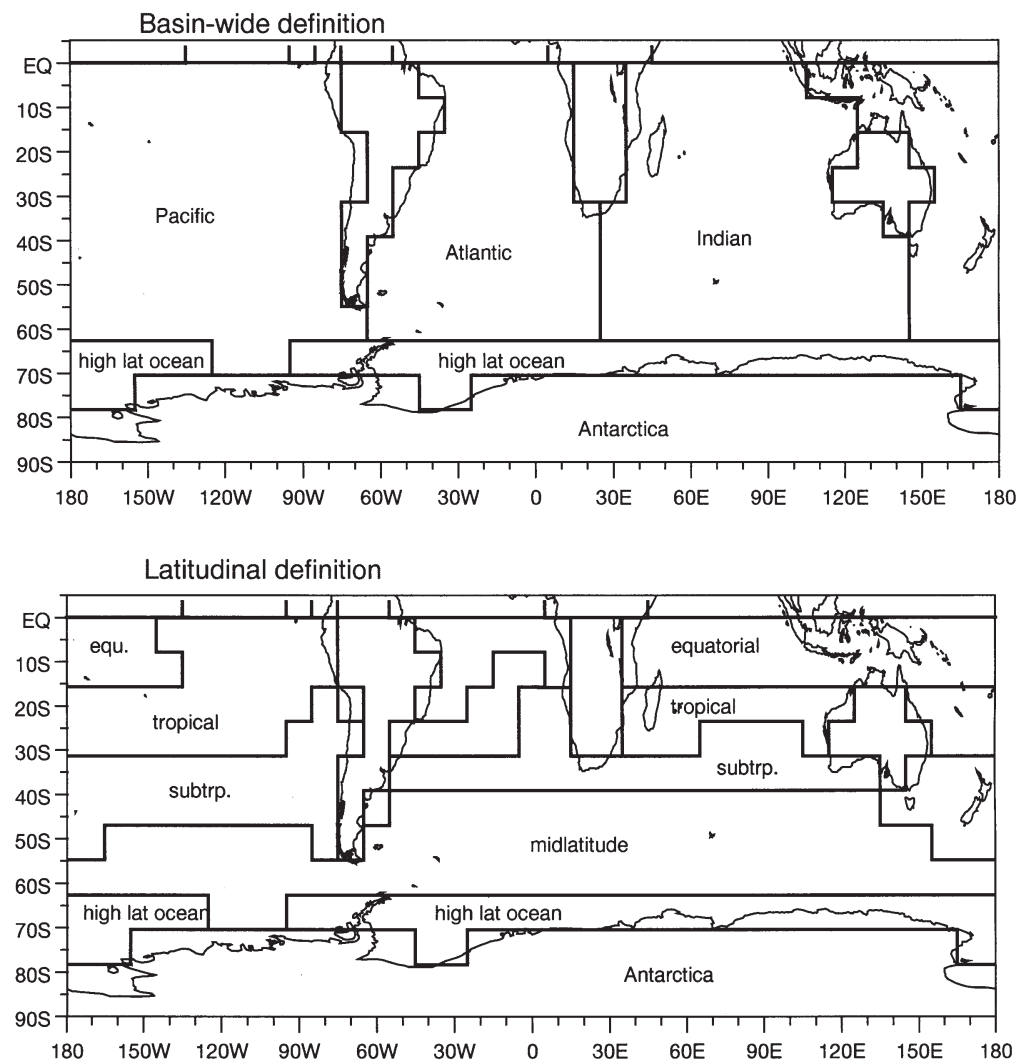

Fig. 2. Definition of the moisture sources for the simulations. Between the Equator and $63^{\circ} \mathrm{S}$, the definition is based on either basin geography or annual sea surface temperature. The "high latitude ocean" source is characterised by a seasonal sea ice cover.

$70 \%$ land were combined into a fourth region, and grid cells within the Antarctic ice sheet and the ocean immediately surrounding it (which is strongly influenced by sea ice) comprise two additional regions. The Antarctic ice sheet is isolated as a source region in order to assess the importance of polar moisture recycling. For some additional analysis, we regrouped the grid cells comprising the three ocean basin source regions into four source regions, defined by their annual SST. Fig. $2 b$ shows this set of source regions, labelled "equatorial", "tropical", "subtropical", and "midlatitude".

\section{Simulation for present-day conditions}

In a 10 -year present-day simulation, we forced the tracer GCM at the ocean boundary with the
1979-1988 SST dataset compiled by Reynolds (1988), used in the Atmospheric Model Intercomparison Project (AMIP; Gates, 1992). The prescribed SSTs thus had realistic interannual variations. Some doubt being cast on the interannual sea ice variability, the 1979-1988 average was used instead for each month sea ice cover. The atmospheric $\mathrm{CO}_{2}$ concentration was set to its early industrial level ( $315 \mathrm{ppmv})$. All other boundary conditions were as described in Hansen et al. (1983).

As an indirect test of the model's ability to transport water tracers correctly, we now examine the resulting simulated water cycle around Antarctica in terms of (1) moisture transport and (2) snow accumulation. In Fig. 3, the simulated zonally-averaged meridional transport of vapour in the southern hemisphere is compared with estimates from operational analyses of the 


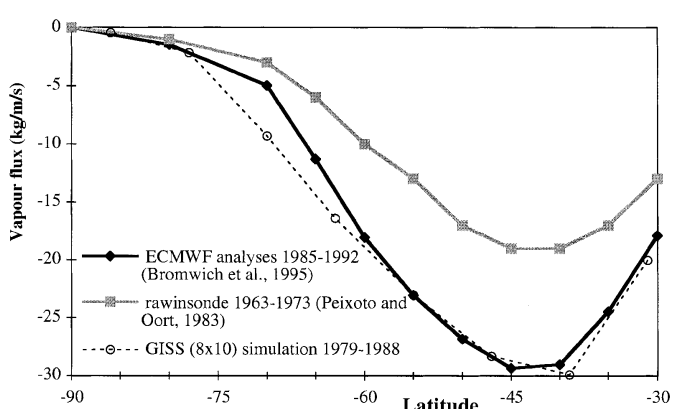

Fig. 3. Annual zonally-averaged meridional transport of moisture by the atmosphere: comparison of estimates based on ECMWF numerical analyses by Bromwich et al. (1995), upper air station data by Peixoto and Oort (1983), and present-day simulation results with the GISS $8^{\circ} \times 10^{\circ}$ AGCM.

ECMWF model (Bromwich et al., 1995). A previous attempt to estimate this flux from upper air station data (Peixóto and Oort, 1983) is also shown to emphasize the uncertainty due to difference in technique, though we note that the ECMWF analysis is considered far more reliable. The transport simulated by the tracer model is in good agreement with the ECMWF estimates at most latitudes, but it is too high over the Antarctic coast (between $65^{\circ} \mathrm{S}$ and $75^{\circ} \mathrm{S}$ ). Indeed, at $70^{\circ} \mathrm{S}$, the simulated poleward flux is $9.2 \mathrm{~kg} / \mathrm{m} / \mathrm{s}$, twice as large as the estimate of $4.6 \mathrm{~kg} / \mathrm{m} / \mathrm{s}$ calculated by Giovinetto et al. (1997) from different numerical analyses. This excessive inland penetration of moisture is probably due to the coarse resolution of the tracer model, which allows an excessive numerical diffusion of moisture and does not simulate the barrier effect of the steep Antarctic coast (Genthon, 1994).

Nevertheless, the model simulates reasonably well the large scale moisture transport from low latitudes to Antarctica. The longitudinal distribution of this transport is mainly controlled by the position of quasi-stationary cyclones along the coast (Bromwich et al., 1995). Fig. 4 shows the simulated annual meridional moisture flux across $70^{\circ} \mathrm{S}$ and the simulated annual sea level pressure around Antarctica, both averaged over the 10-year run. Although the absolute pressure values are too high by about $20 \mathrm{hPa}$, the pattern of pressure lows corresponds to the numerical analysis-based estimates of Bromwich et al. (1995). The stationary behaviour of these lows in the simulation is con- firmed by a small associated variability; the standard deviation of sea level pressure is roughly 5 to $10 \mathrm{hPa}$ on both seasonal and interannual timescales.

The meridional fluxes across $70^{\circ} \mathrm{S}$ are, as expected, well correlated with the local cyclonic pattern, i.e., they are systematically southward on the eastern side of a low center and northward on the western side. The strongest simulated moisture transport is associated with the BellingshausenAmundsen and Weddell Sea pressure lows, in agreement with other studies, although the Weddell Sea low and transport are too pronounced (Bromwich et al., 1995). It is not clear, however, whether these strong fluxes in nature result only from regional conditions (low pressure centres; latent heat flux from oceanic evaporation) or from cyclonic track feed (Jones and Simmonds, 1993). The model does shift westward by $30^{\circ}$ the cyclonic centre that exists at about $120^{\circ} \mathrm{W}$ (Amundsen Sea), and this could unrealistically decrease the contribution of East Pacific moisture into West Antarctica. Overall, though, the model simulates a correct longitudinal distribution of moisture inflow from the coast to the ice sheet.

The simulated snow accumulation over Antarctica is $30 \mathrm{~cm} /$ year, which is about twice as large as estimates derived from operational numerical analyses (Budd et al., 1995; Bromwich et al., 1995) and AGCMs run at higher resolution (Genthon, 1994). The excessive accumulation corresponds, in fact, to the excessive meridional vapour flux at $70^{\circ} \mathrm{S}$, shown earlier in Fig. 3. Our concerns about the excess annual accumulation are mitigated somewhat by the fact that the model reproduces a realistic seasonal cycle of precipitation (Fig. 5). The model simulates maxima of both precipitation and net accumulation in early fall (March-April), a precipitation minimum in spring (September) and an accumulation minimum in summer (December-January), which compares well with numerical analysis (Bromwich et al., 1995) and high resolution modelling studies (Tzeng et al., 1994; Krinner et al., 1997b).

Fig. 6 shows that in the areas surrounding the Vostok station in central Antarctica (represented by a 4-grid cell average) and the Law Dome station on the coast ( 2 grid cells), the seasonal cycles of the precipitation are reasonable when compared to the data of Dolgina and Petrova (1977) for Vostok and Casey/Wilkes (close to Law 

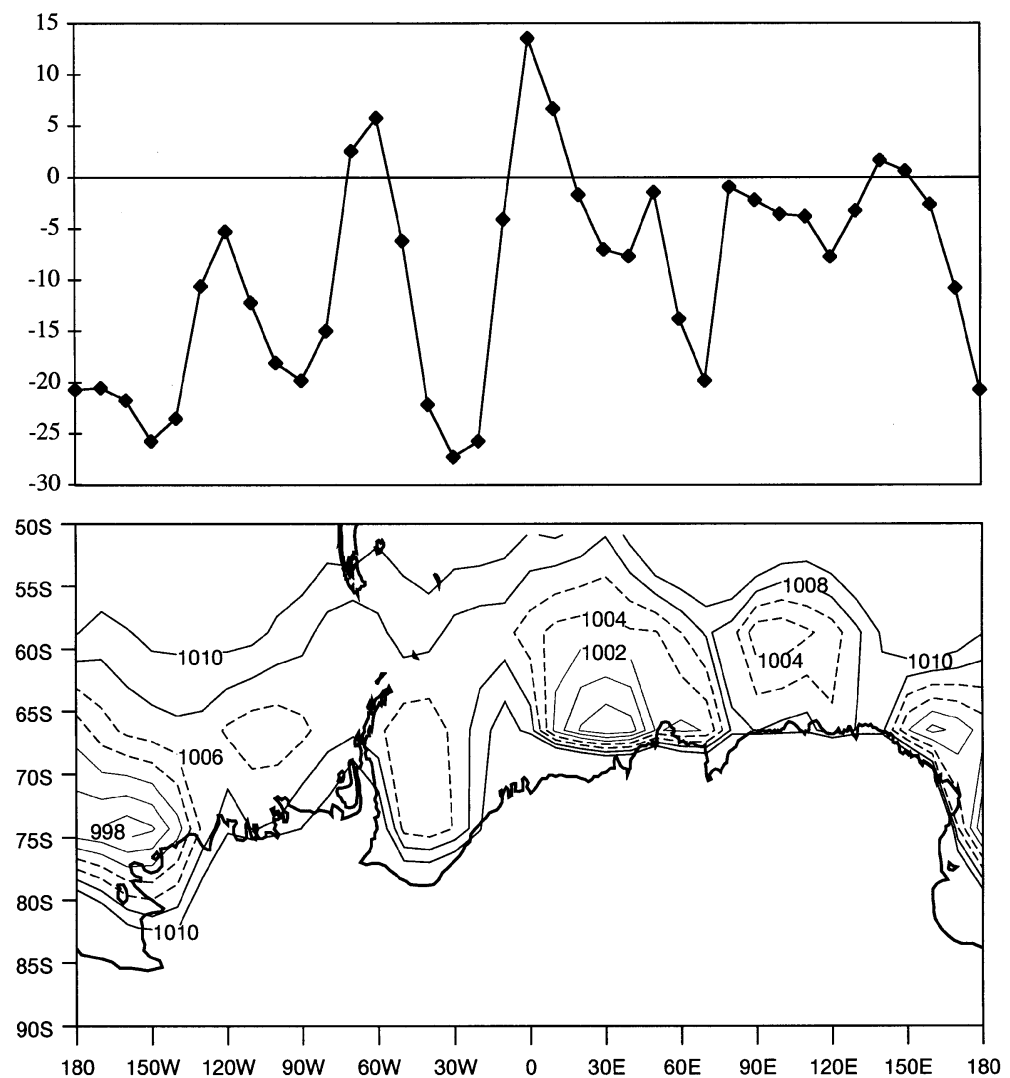

Fig. 4. 1979-1988 annual averages simulated by the GISS model of (top) meridional northward moisture transport across $70^{\circ} \mathrm{S}$ latitude (in $\mathrm{kg} / \mathrm{m} / \mathrm{s}$ ); and (bottom) sea level pressure (isobars every $2 \mathrm{hPa}$ from 998 to 1010). Note the pattern of quasi-stationary lows around Antarctica.

Dome). The simulated seasonal amplitudes are a little weak, but we note that the quoted observations rely, in part, on wind corrections to gauge measurements, which can sometimes increase the observed amplitudes dramatically. More recent observations for Law Dome (Vin Morgan, personal communication, 1997) suggest a significantly weaker seasonal cycle for the precipitation.

The simulated accumulation shows an overly weak interannual variability. The standard deviation of annual accumulation is about $0.6 \mathrm{~cm} /$ year, which is much lower than the $30 \%$ interannual variation inferred from ECMWF analyses by Cullather et al. (1996). We do not expect that the inclusion of interannual variability in sea ice cover (neglected in the present simulation) would increase significantly the variability of accumulation, a similar low one was found in a simulation that includes these sea ice variations (Krinner et al., 1997b).

In summary, the GCM simulation of the hydrologic cycle has some important biases that must be considered when interpreting the model results. Overall, though, model accuracy is deemed sufficient for the first-order analyses described below.

\subsection{Latitudinal contribution to precipitation}

The relative contributions of the 6 "latitudinal" sources defined in Figure 2 to Antarctic precipitation are shown on Table 1. Also included are relevant physical characteristics of each evaporative source, namely the area, surface temperature, and local water budget. Notice that differences in the areal extent of the four warmest oceanic 


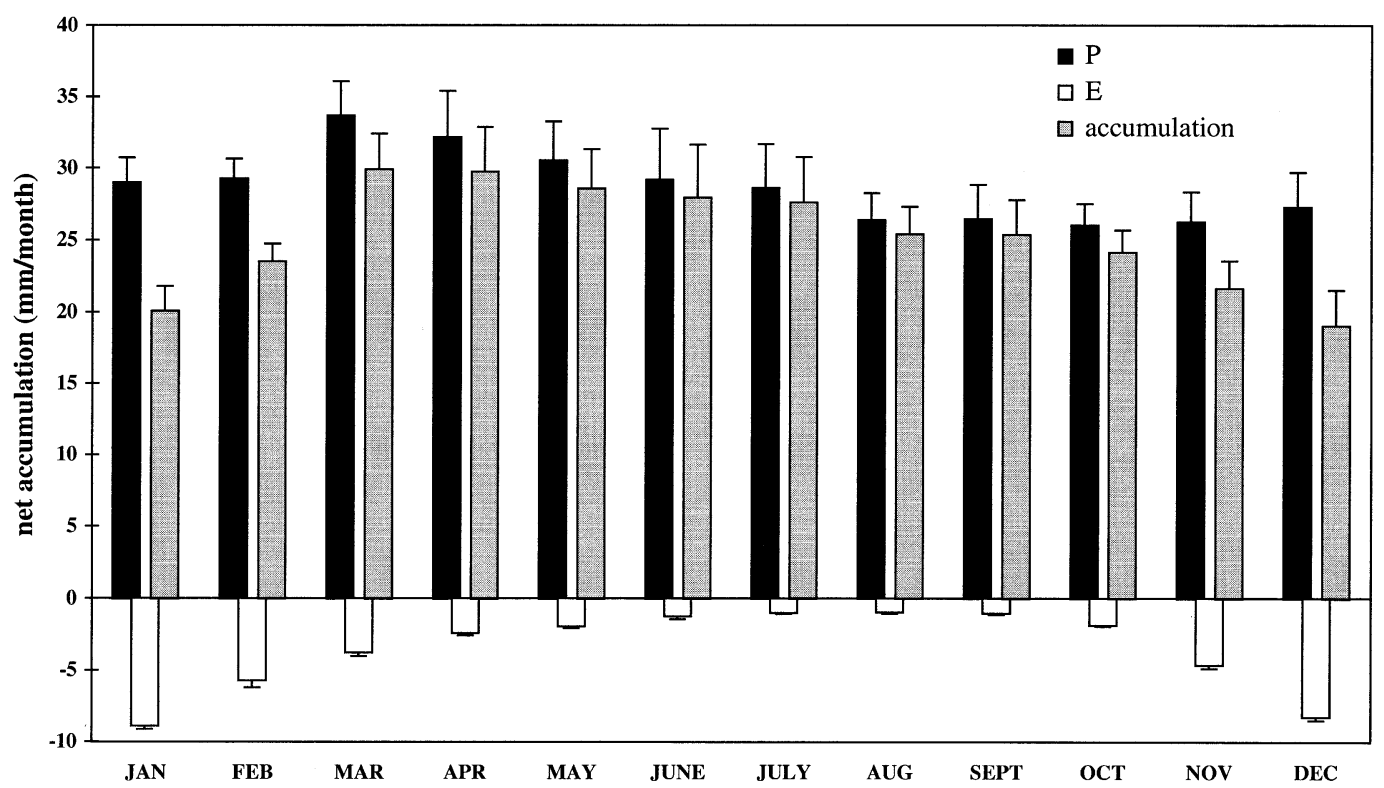

Fig. 5. 1979-1988 averages of precipitation, sublimation and net accumulation (in mm/month) simulated over Antarctica with the GISS AGCM.

sources cannot explain more than $15 \%$ of their listed differences in evaporative contribution. Total evaporation from each source represents its potential role in providing vapour to the atmospheric water cycle. Evaporation minus precipitation indicates the net export of vapour to the atmosphere, but this cannot be interpreted in term of vapour origin because part of the local precipitation may originate elsewhere.

The "equatorial" zone provides less than $5 \%$ of the moisture precipitating in Antarctica. The "tropical" zone, which is the strongest tracer source (evaporation is largest), contributes less than $15 \%$. The small contributions of these two zones are consistent with the nature of the Hadley circulation, which keeps much of the tropical vapour away from southern latitudes. The small contribution of the "equatorial" region in particular can be explained by a high local turnover of moisture, as indicated by the small net moisture divergence (E-P) there.

The "subtropical" and "midlatitude" zones (between roughly 30 and $63^{\circ} \mathrm{S}$ ) are the main contributors to Antarctic precipitation, providing up to two-thirds of the total. Notice that the "midlatitude" zone, despite its large contribution, is effectively a vapour sink, with a negative net moisture divergence. This implies that much of the precipitation onto this oceanic region is simulated as derived from external (presumably equatorward) sources. In effect, much of the water travelling poleward from these external sources rains out, and some of it is replaced by the evaporated midlatitude water.

Despite its low temperatures and correspondingly low evaporation rates, the polar oceanic zone around Antarctica supplies up to one fifth of Antarctica's precipitation during austral summer and fall (Fig. 9). The source contribution during austral winter is significantly lower. This seasonality corresponds well with that of sea ice area (Giovinetto et al., 1997, Fig. 4); the evaporation being highest when sea ice area is smallest. Most of the local oceanic moisture is derived from the Weddell and Ross seas, where leads and polynyas (parameterized as fractional sea ice in the model) can allow an important air-sea exchange.

Continental water recycling in Antarctica is not significant on the annual scale, as indicated by the small contribution listed in Table 1 for the "Antarctic" tracer. This small contribution stems from the extremely cold surface temperatures 

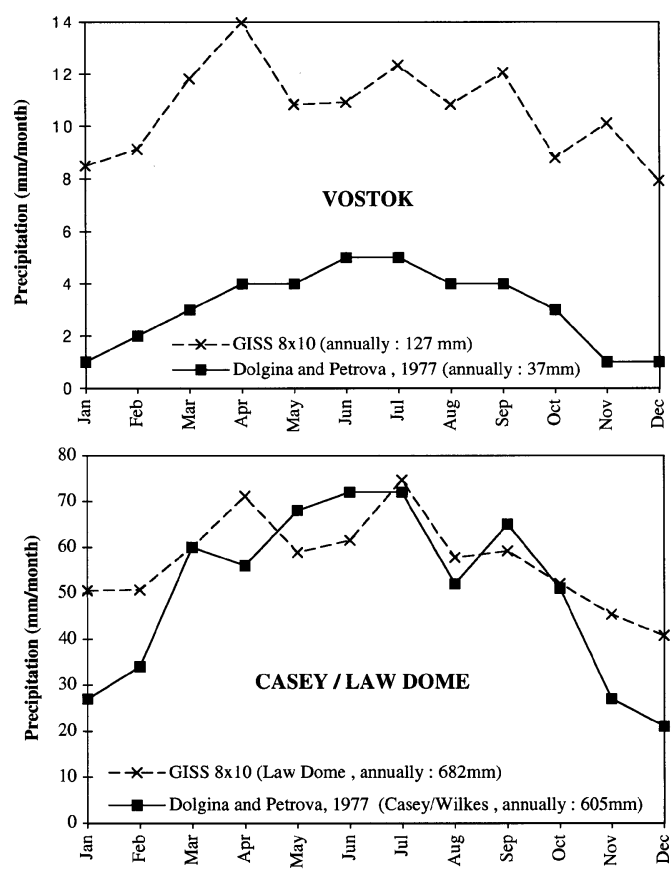

Fig. 6. 1979-1988 average of precipitation (in $\mathrm{mm} / \mathrm{month}$ ) for central and coastal Antarctic stations: simulated values for Vostok and Law Dome areas (weighted averages of 4 and 2 grid points, respectively) versus estimates of Dolgina and Petrova (1977) for Vostok and Casey/Wilkes stations.

there, which lead to low sublimation rates. This contribution is significant (up to $20 \%$ of the total) only during austral summer in central Antarctica, where the advection of moisture is small.

One measure of the interannual variability of a relative contribution is the ratio of the standard deviation of the contribution to its ten-year average. In different Antarctic places, this ratio is generally less than $30 \%$, which is similar to the ratio describing the interannual variability of measured Antarctic precipitation (Bromwich, 1988). Higher values of the ratio are usually found for the evaporative sources contributing the least; e.g., the ratio for the Antarctic source is close to $70 \%$.

The contribution strengths discussed above are calculated for areally-averaged Antarctic precipitation. When tracer precipitation rates at individual grid cells are analyzed, we find in addition that the relative importance of the different evap- orative sources varies geographically across Antarctica.

Fig. 7 shows, for austral winter and summer, the variation of source contribution with latitude over East Antarctica. Notice that the relative contributions of the midlatitude and high latitude oceanic sources decrease toward the pole, whereas those of the lower latitude sources slightly increase especially in winter. This is consistent with an idea earlier espoused by Petit et al. (1991), Koster et al. (1992), and Ciais et al. (1995): moisture from different oceanic sources is generally transported at different atmospheric levels, and this allows the more remotely derived moisture to penetrate further poleward.

Fig. 7 also illustrates that the contributions from the different sources vary seasonally. This seasonality results from the interplay between cyclonic intensity, which is strongest in austral winter; sea ice growth, which modulates the vapour supply from the cold ocean, with a peak in fall; and continental water recycling, which is small but relevant in summer.

Looking at the annual contributions to precipitation across Antarctica, we can compute for each grid cell an average source temperature, $T$-ave, by multiplying each source average temperature, $\mathrm{Ti}$, by the source contribution to the grid cell precipitation, $\mathrm{Pi}$, and then dividing the sum of these products by the total tracer precipitation: $T$-ave $=$ $\Sigma(\mathrm{Ti} \cdot \mathrm{Pi}) / \Sigma(\mathrm{Pi})$. We consider only the oceanic sources for this calculation, since (i) these sources supply most of the precipitation water, (ii) it allows a direct comparison with simple isotopic model, and (iii) for isotope calculations, the relationship between source temperature and the isotopic character of the evaporate is stronger over the ocean. Fig. 8 shows the spatial distribution of $T$-ave in Antarctica. These average source temperatures are slightly warmer than those calculated by Koster et al. (1992) with the same model (for July and with different SSTs), the averages of $T$ ave over Antarctica for July are $11.9^{\circ} \mathrm{C}$ (10-year std: $0.6^{\circ} \mathrm{C}$ ) in the present study and $11.6^{\circ} \mathrm{C}$ in the earlier one. The annual average is $11.3^{\circ} \mathrm{C}$ (with a 10 -year standard deviation of $0.2^{\circ} \mathrm{C}$ ), reflecting the impact of seasonality on the source contributions: during the summer, although sources are warmer, the coolest sources participate more so that the annual source temperature average is cooler than that for austral winter. Fig. 8 shows that the spatial 
Table 1. Average contributions of the different zones (Fig. 2) to Antarctic precipitation, as simulated by the GISS model for modern and ice age conditions

\begin{tabular}{|c|c|c|c|c|c|}
\hline \multicolumn{2}{|c|}{$\begin{array}{l}\text { Source area and contribution } \\
\text { to Antarctic precipitations in } \\
\text { percent, for modern, CLIMAP and } \\
\text { cooler tropics LGM simulations }\end{array}$} & \multirow{2}{*}{$\begin{array}{c}\begin{array}{c}\text { Annual average } \\
\text { and range of } \\
\text { surface temperature }\end{array} \\
24<27.7>29\end{array}$} & \multicolumn{3}{|c|}{$\begin{array}{l}\text { Evaporation, precipitation and } \\
\text { E-P balance }\left(10^{15} \mathrm{~kg} / \mathrm{yr}\right)\end{array}$} \\
\hline "equatorial" zone & $1<3>4$ & & 77.6 & 77.1 & 0.4 \\
\hline \multirow{2}{*}{$\left(46 \cdot 10^{12} \mathrm{~m}^{2}\right)$} & $2<2>3$ & $21<26.3>28$ & 71.2 & 71.5 & -0.3 \\
\hline & $2<3>4$ & $18<24.7>27$ & 71.3 & 68.7 & 2.6 \\
\hline "tropical" zone & $10<13>15$ & $20<23.9>27$ & 87.3 & 53.4 & 33.8 \\
\hline \multirow[t]{2}{*}{$\left(54 \cdot 10^{12} \mathrm{~m}^{2}\right)$} & $15<16>18$ & $17<24.0>27$ & 90.2 & 62.8 & 27.4 \\
\hline & $12<14>16$ & $17<21.2>24$ & 81.6 & 49.6 & 32.0 \\
\hline "subtropical" zone & $25<28>30$ & $8<16.3>22$ & 65.0 & 52.8 & 12.2 \\
\hline \multirow[t]{2}{*}{$\left(48 \cdot 10^{12} \mathrm{~m}^{2}\right)$} & $33<38>42$ & $4<16.0>22$ & 68.8 & 53.1 & 15.7 \\
\hline & $29<34>40$ & $4<13.8>19$ & 59.7 & 51.0 & 8.7 \\
\hline "midlatitude" zone & $29<36>41$ & $-1<6.9>12$ & 29.1 & 46.1 & -17.0 \\
\hline \multirow[t]{2}{*}{$\left(51 \cdot 10^{12} \mathrm{~m}^{2}\right)$} & $27<31>35$ & $-1<4.6>10$ & 22.8 & 39.9 & -17.1 \\
\hline & $31<35>39$ & $-2<4.3>9$ & 24.3 & 37.9 & -13.6 \\
\hline "high lat. ocean" & $7<12>18$ & -1.5 & 2.6 & 8.3 & -5.7 \\
\hline \multirow[t]{2}{*}{ zone $\left(14 \cdot 10^{12} \mathrm{~m}^{2}\right)$} & $3<6>12$ & -1.6 & 1.2 & 7.2 & -6.0 \\
\hline & $3<7>14$ & -1.8 & 1.2 & 6.4 & -5.2 \\
\hline "Antarctic" zone & $2<4>10$ & $<-15$ & 0.3 & 4.3 & -3.9 \\
\hline \multirow{2}{*}{$\left(13 \cdot 10^{12} \mathrm{~m}^{2}\right)$} & $1<2>6$ & $<-20$ & 0.2 & 3.5 & -3.3 \\
\hline & $1<2>6$ & $<-20$ & 0.2 & 3.0 & -2.8 \\
\hline
\end{tabular}

Annual average and seasonal extrema are given for each zone, as well as the zone area $\left(10^{12} \mathrm{~m}^{2}\right)$, the spatial range of annual surface temperature $\left({ }^{\circ} \mathrm{C}\right)$, and the hydrological balance (fluxes $\left(10^{15} \mathrm{~kg} / \mathrm{yr}\right)$ ). The ice age simulations consist of a full CLIMAP simulation and a simulation in which cooler tropics are imposed.

distribution of $T$-ave is similar to that found by Koster et al. (1992). Slightly higher values of $T$ ave lie near the pole, reflecting a relatively stronger contribution from remote sources there.

These average source temperatures, by the way, are at odds with the results of Petit et al. (1991) and Ciais et al. (1995), who addressed the problem by analyzing snow isotope data in the context of a Rayleigh distillation model. Although they could not rule out small contributions of moisture from higher latitudes and the coastal ocean, they inferred the dominant source of Antarctic precipitation to be the subtropical ocean, at $30^{\circ}-40^{\circ} \mathrm{S}$ in the former study, and $20^{\circ}-40^{\circ} \mathrm{S}$ in the latter. Interestingly, using the same Rayleigh model, Delmotte (1997) inferred a significant contribution of high latitude sources to the precipitation at the coastal site of Law Dome. The Rayleigh distillation model, of course, is highly idealized and cannot account for the complexity inherent in atmospheric processes to the extent that a threedimensional AGCM can. In particular Delmotte
(1997) pointed out to the strong sensitivity of this simple model to isotopic initial conditions, poorly estimated in the previous studies (Jouzel and Koster, 1996). We thus consider our AGCM results to be more reliable.

\subsection{Basin contribution to precipitation}

The North Atlantic is often considered a source of rapid climatic change through its control on the thermohaline circulation (Broecker, 1997). Data and model analysis (Blunier et al., 1998; Kim et al., 1998), however, suggest that the ocean circulation in high southern latitudes may also play an important role. We might expect that climatic changes in zonal SSTs and meridional heat fluxes may differ significantly in the Atlantic, Pacific, and Indian Oceans and that such differences may be imprinted on the isotopic composition of the vapor evaporating from the basins. A major goal of EPICA is to examine the potential for such differences through the analysis of long 

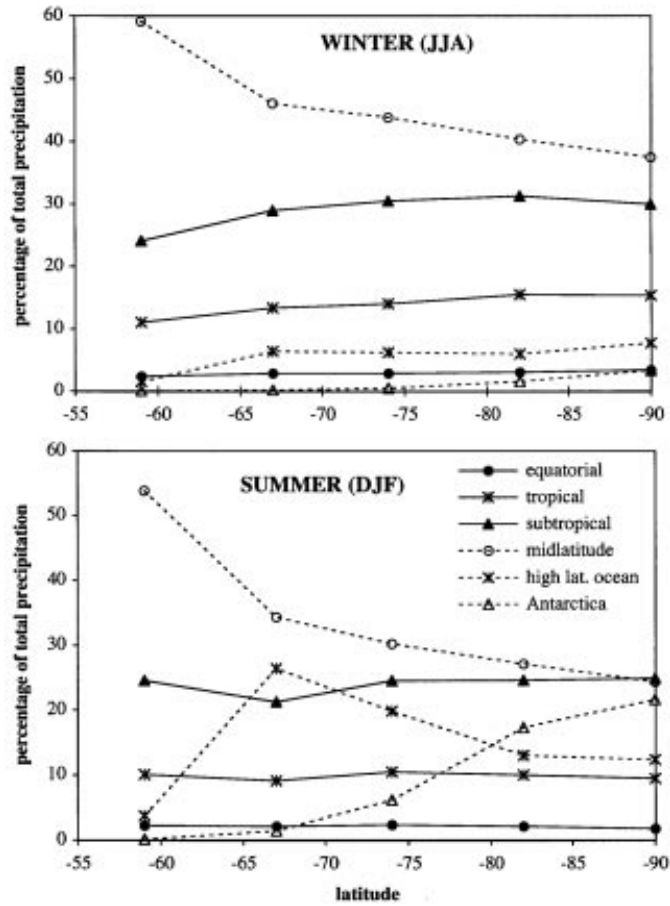

Fig. 7. Latitudinal variation of moisture source contributions to East Antarctica precipitation (1979-1988 average), as simulated by the GISS model for austral winter (JJA) and summer (DJF). Note the significant seasonal variation in the high latitude and Antarctic contributions.

term isotopic profiles from two different sites: Dome Concordia, which is situated in the Indian Ocean sector, and Dronning Maud Land, in the Atlantic sector.

Using the ocean basin tracers defined in Fig. 2, we can examine with our present-day GCM simulation the contribution of each basin to Antarctic precipitation. Fig. 9 shows these contributions, in percent, for the seasons exhibiting the greatest contrast. The GISS model clearly locates each basin domain of influence inside its longitudinal limits, the maximum influence being shifted eastward by $10^{\circ}$ to $20^{\circ}$ relative to the basin center, which is consistent with the cyclonic circulation that supplies moisture to Antarctica. Each basin contribution decreases rapidly poleward, the $50 \%$ isolines are generally not far from the coast. Moisture from the Indian Ocean, however, penetrates far inland during austral winter, and Pacific moisture largely dominates West Antarctica.
Fig. 10 shows, as a function of month, the breakdown of the tracer contributions to precipitation in the regions surrounding Vostok on the Central Plateau and the EPICA drilling site in Dronning Maud Land $\left(75-77^{\circ} \mathrm{S} ; 0-10^{\circ} \mathrm{E}\right)$. Results shown are averages over several grid cells (see caption). The Vostok region is mainly under the influence of the Indian Ocean, which contributes $30 \%$ of the moisture during austral summer and $60 \%$ during austral winter. The high latitude ocean source is important during austral summer, supplying up to $25 \%$ of the moisture then. The model simulates similar contributions (not shown) for Dome Concordia, the other EPICA drilling site $\left(74.5^{\circ} \mathrm{S} ; 123^{\circ} \mathrm{E}\right)$, but with a higher contribution from the Indian Ocean ( $75 \%$ in July).

Precipitation in the Dronning Maud Land region is less dominated by a single ocean basin source. The closest ocean, the Atlantic, does supply most of the moisture $(42 \%$ on average and up to $60 \%$ at the end of austral winter), but the Pacific Ocean supplies $20-30 \%$ of the moisture throughout the year, and the high latitude ocean source is strong in austral fall, when it provides $30 \%$ of the moisture. Such a strong contribution from a high latitude source was inferred by Turner et al. (1995) for a different coastal region (the Rothera station on the west coast of the Peninsula) from synoptic observations: about half of the depressions that led to precipitation at this station during a year of study had formed south of $60^{\circ} \mathrm{S}$. Seasonality in the high latitude source contribution is clearly seen at Dronning Maud Land, which lies near the coast; the maximum contribution is in austral fall, when the sea ice cover is smallest. On the central plateau (Vostok, Dome C), such seasonality is damped by the lower latitude contributions, which increase in austral fall due to a more intense cyclonic activity.

Our simulation for present-day suggests that places characterised by low accumulation rates (where long ice records are possible) and dominated by moisture contributions from a single oceanic basin are restricted to the eastern end of the central plateau. The western end is at a crossroads of different influences. But simulations for the last glacial maximum, in the following, show that the contribution of the most important source, at each place, increases with ice age conditions. 

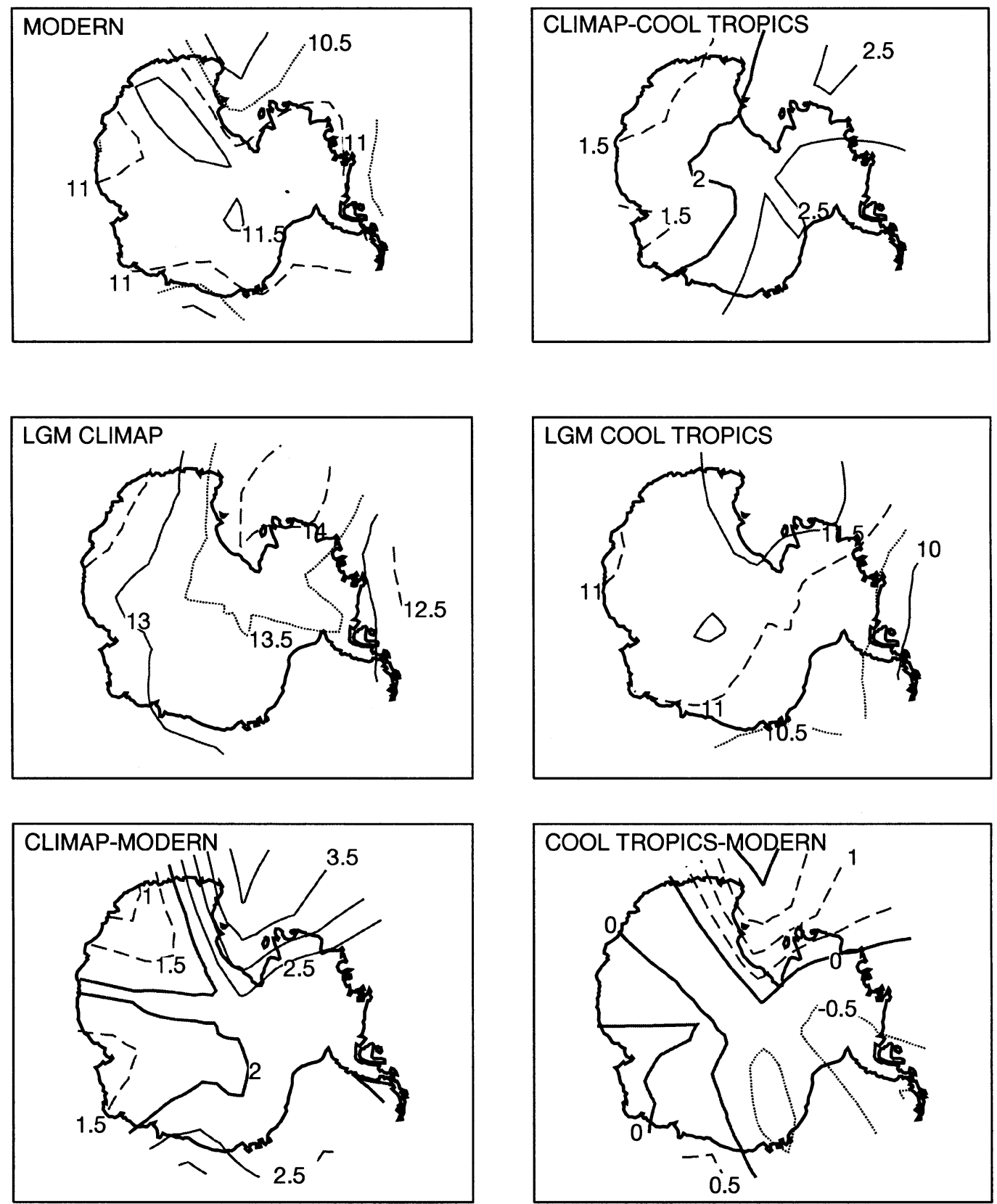

Fig. 8. Average oceanic source temperature, $T$-ave, in ${ }^{\circ} \mathrm{C}$, for annual precipitation under present-day and LGM conditions. Differences in $T$-ave between LGM and present-day conditions are also shown. 

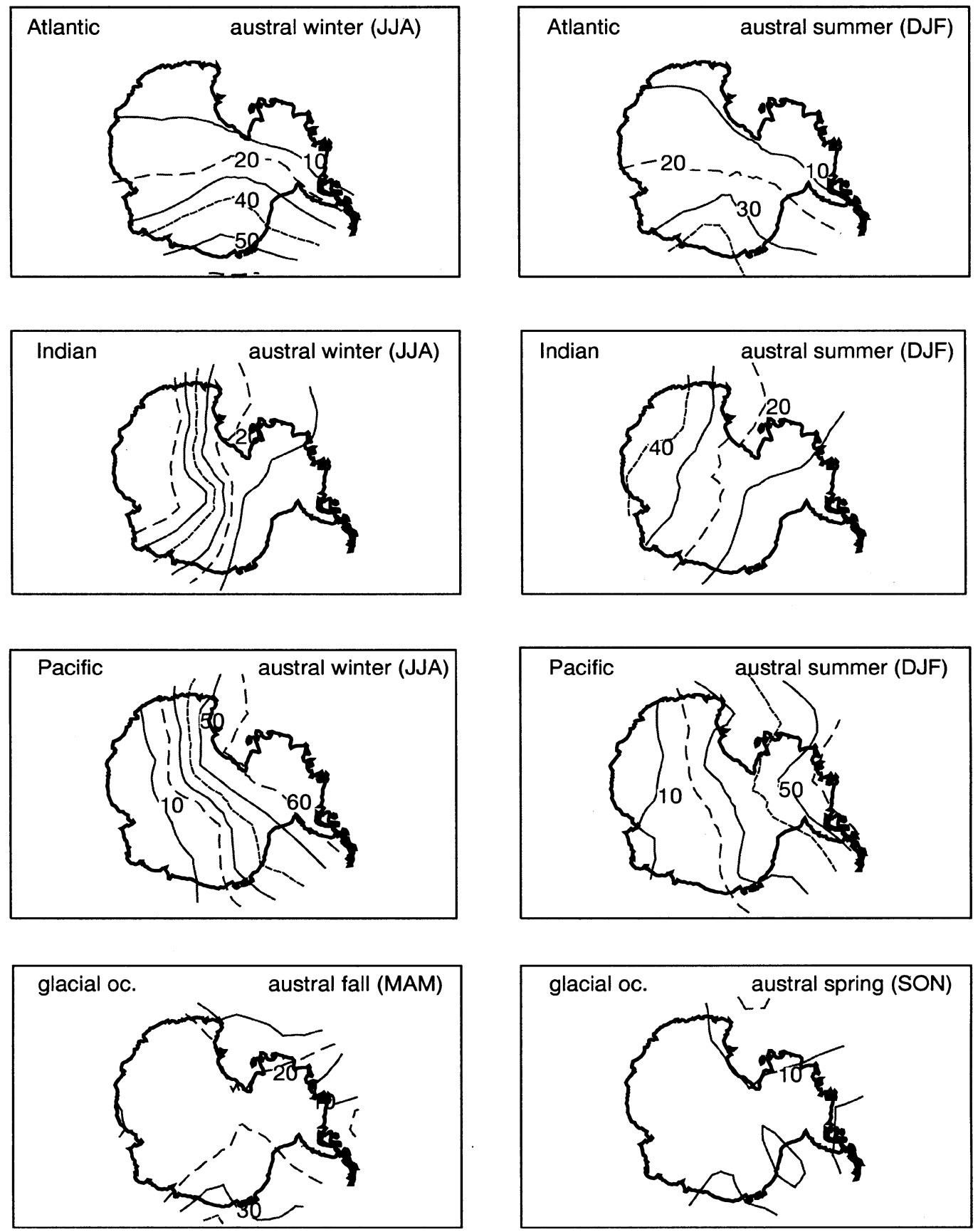

Fig. 9. 1979-1988 average of the contributions of different ocean basins (Fig. 2) to the precipitation simulated by the GISS model, shown as a percent of total precipitation. The two seasons with the most extreme differences are shown for each ocean basin. Isolines are at every $10 \%$, from 10 to $60 \%$. 

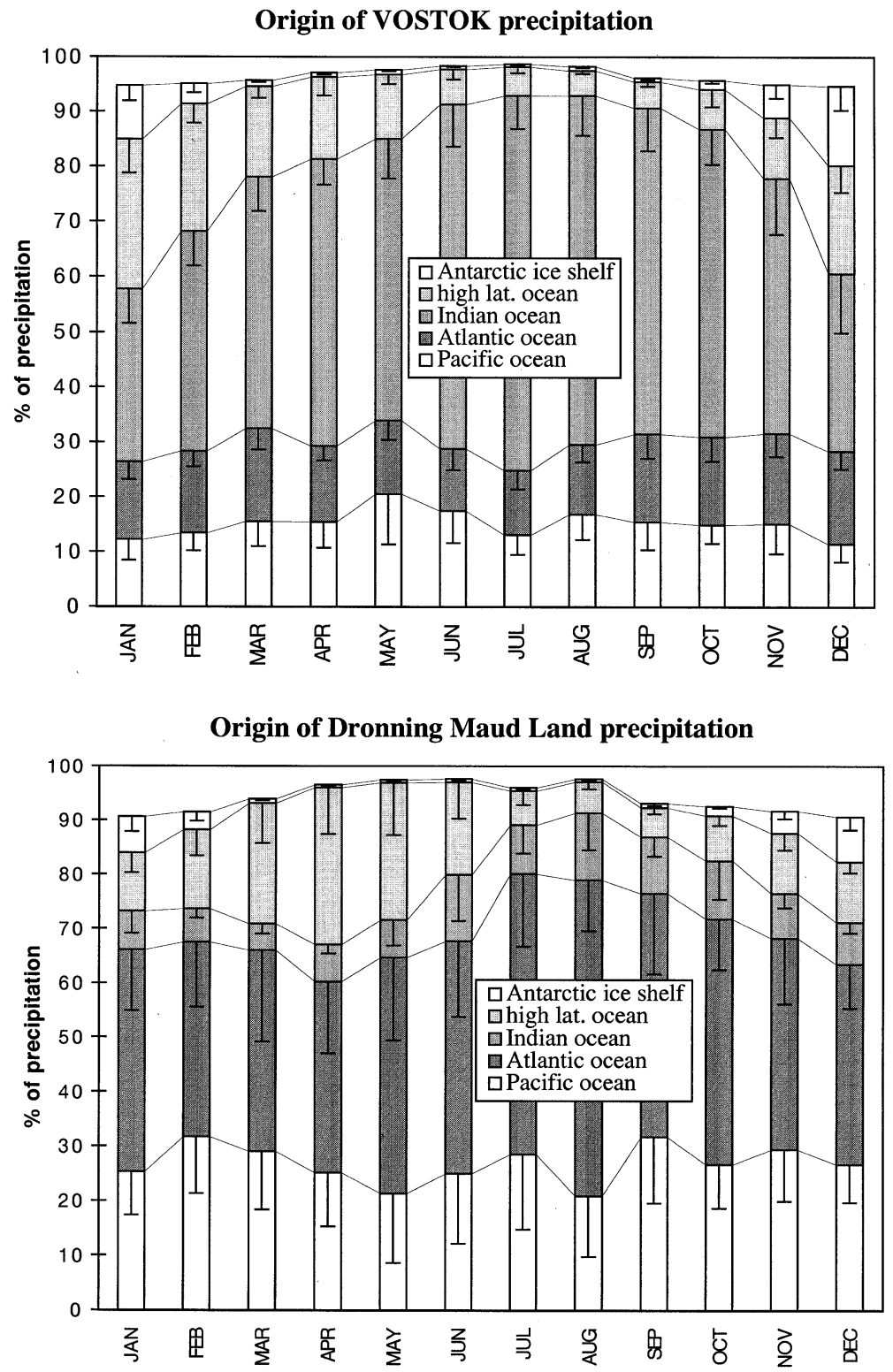

Fig. 10. Annual source contributions to two areas: the Vostok region (on the Central Plateau, with a simulated annual temperature of $\left.-49^{\circ} \mathrm{C}\right)$ and the potential drilling site of EPICA in Dronning Maud Land $\left(75-77^{\circ} \mathrm{S}, 0-10^{\circ} \mathrm{E}\right.$; simulated annual temperature: $-40^{\circ} \mathrm{C}$ ). Results shown are weighted averages over 4 and 2 grid points, respectively. Each error bar represents one standard deviation, as determined from the 10 simulation years. Contributions from the source missing in the figure (nonpolar continents) would bring the total to $100 \%$. 


\section{Simulation for the last glacial maximum conditions}

\subsection{Description of experiments and simulated climates}

As noted in the introduction, a better understanding of how evaporative source temperature changes with climate may improve our ability to interpret isotope paleodata. With this in mind, we performed two additional simulations with the tracer GCM, each one focusing on the climate of the last glacial maximum (LGM, about 21 thousands of years -ka- ago).

The first simulation used the CLIMAP (1981) reconstruction of topography, sea surface temperatures and sea ice cover. The reconstructed Antarctic elevation was generally increased by several hundred meters and up to a thousand meters in the west. An ablation of 200-500 meters took place along the eastern coast. $\mathrm{CO}_{2}$ concentration was lowered to $200 \mathrm{ppmv}$ (Raynaud et al., 1993) and orbital parameters were set to values corresponding to $21 \mathrm{ka}$ ago (Berger, 1978). Aside from this last change, by the way, the climatic aspects of this simulation are identical to those in the ice age simulation described by Rind (1987), which used insolation parameters corresponding to $18 \mathrm{ka}$ years ago.

The second LGM simulation was performed to address uncertainty in the reconstructed intertropical SSTs provided by CLIMAP — some (Rind and Peteet, 1985; Pinot et al., 1999) believe that these SSTs are significantly too high. The nature of the intertropical SSTs is important in our analysis, of course, given the sensitivity of the global hydrologic cycle to the spatial distribution of SSTs and particularly to their meridional gradient. In the second LGM simulation, we cooled intertropical SSTs by 2 to $3^{\circ}$ relative to modern conditions: (a) in the Atlantic Ocean we applied a $3^{\circ}$ cooling between about $40^{\circ} \mathrm{S}$ to $25^{\circ} \mathrm{N}$; (b) in the Pacific Ocean we applied a $2^{\circ}$ cooling from about $48^{\circ} \mathrm{S}$ to $38^{\circ} \mathrm{S}$; and (c) in the Indian Ocean, we applied a $2^{\circ}$ cooling in each cell north of $26^{\circ} \mathrm{S}$. This somehow arbitrary reconstruction is based on independent proxies, such as alkenones and corals (Edouard Bard, personal communication, 1997), and it is roughly consistent with output from coupled atmosphere-ocean simulations of LGM climate (Ganopolski et al., 1998). This imposed cooling lies between the severe cooling seen on the continent and the sea surface stability that can be inferred from faunal assemblages.

The prescribed conditions in both LGM simulations have no interannual variability, so both simulations were integrated for only 5 years, after a one month spin-up period. The analysis below focuses on the monthly averages derived from these 5 years. The interannual variability of the simulated fields is found to be comparable to that in the present-day run, which uses interannually varying SSTs. Hence, we infer that glacial conditions increase the intrinsic atmospheric variability, partly through the transient eddy circulation (Rind, 1987).

The meridional vapour flux simulated with standard CLIMAP conditions is very similar to that simulated in the present-day run (Fig. 11), except for a $10^{\circ}$ southward shift of the transport maximum consistent with the largest latitudinal gradient of temperature (Rind, 1987). Compared to the CLIMAP simulation, the cooler tropics imposed in the second LGM simulation lead to lower high latitude temperatures (by $1-2^{\circ}$ ), but the net effect of this cooling in low and high latitudes is a weaker meridional temperature gradient. The southward flow is reduced in this "cooler tropics" simulation (by 15\%) compared to present-day, due to the decrease of both global evaporation and meridional transport.

In both LGM simulations, the net accumulation over Antarctica is reduced by about $20 \%$ - the $50 \%$ reduction in annual sublimation induced by

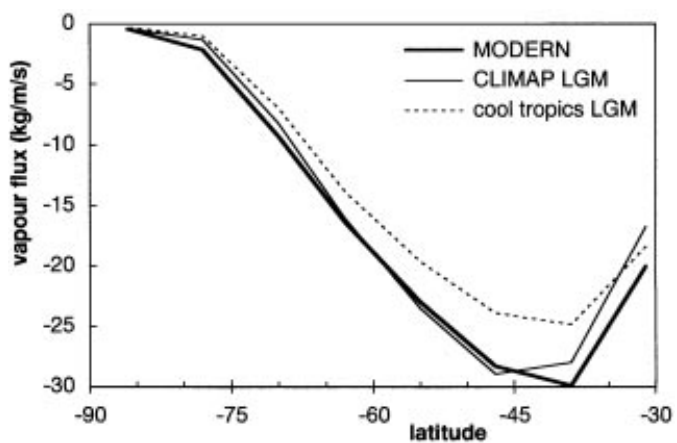

Fig. 11. Annual zonally-averaged northward flux of vapour (in $\mathrm{kg} / \mathrm{m} / \mathrm{s}$ ) simulated by the GISS model for three different climates: present-day, representing the 1979-1988 period, the LGM using the CLIMAP reconstruction, and the LGM using a CLIMAP with "cooler tropics" reconstruction (see text for details). 
lower surface temperatures is not enough to overcome a concurrent reduction in precipitation $(-22 \%$ for the CLIMAP simulation, $-28 \%$ for the cool tropics one). Due to a drop in sea level, however, Antarctica's area as reconstructed for the LGM is larger by $18 \%$. Averaged over this larger area, reductions in both precipitation and evaporation are smaller $(-6 \%$ and $-22 \%$ respectively for CLIMAP conditions, $-20 \%$ and $-34 \%$ with cooler tropics). The seasonal variation of precipitation is shifted into phase with the solar cycle, with extrema in summer and winter concurrently with sublimation. As a result, the seasonal cycle of accumulation is quite muted since precipitation and sublimation are in antiphase. This seasonal shift of precipitation, which is also seen in the tracer contributions, may reflect our seasonal interpolation of the CLIMAP SSTs and sea ice cover, which assumes extrema in February and August and a sinusoidal cycle in between, and is different from the modern seasonality at least for the sea ice cover (see Subsection 3.1).

In the CLIMAP simulation, the simulated cooling over Central Antarctica $\left(-3.5^{\circ}\right.$ annually) appears to cause the simulated decrease in precipitation there. We conclude this from an analysis in which we scaled the LGM precipitation rates by a factor equal to the ratio of the present-day saturated vapour pressure (as infer-red from surface air temperature and pressure) to that of the LGM. These scaled precipitation rates are quite similar to the simulated present-day rates in Central Antarctica, with a regression slope of 0.95 $\left(r^{2}=0.85, n=575\right)$. Such a correlation between surface temperature and precipitation in Central Antarctica was already inferred from estimates of past accumulation and temperature in deep ice cores (Yiou et al., 1985). This correlation, however, does not hold over all of Antarctica; simulated LGM precipitation in West Antarctica is higher than expected from the cooling alone. This might be explained by higher cyclonic activity in the west and its provision of greater amounts of moisture there. Indeed, in an LGM simulation with a stretched-grid AGCM, Krinner et al. (1997b) simulated a smaller decrease of this cyclonic activity along the coast of West Antarctica than anywhere else on the continent.

\subsection{Contributions from tracer source regions}

For consistency, we used the geographical definition of the moisture sources shown in Fig. 2 in the two LGM simulations, despite the fact that the SSTs within these regions are less homogeneous during the LGM. Results are shown in Table 1 for the whole Antarctic continent. The relative contribution of each source is similar to that found for present-day conditions. The similarity in the relative source contributions between climates also holds at each grid cell in Antarctica. Small differences between the runs are generally comparable in magnitude to the interannual variability and thus must be considered with care. Still, they form a consistent picture when considered along with other climatic differences.

In the CLIMAP simulation, the moisture contribution from low latitudes is generally increased, particularly from the Pacific in West Antarctica. This is perhaps related to the CLIMAP SST reconstruction in the tropics, which: (1) increases tropical evaporation, primarily through a warming of the Pacific, and (2) increases wind strength in the Atlantic through a larger meridional gradient of SST (Miller and Russell, 1990). Outside of the tropics, the simulated increase in the atmospheric transport of energy is quite limited (Rind, 1987).

In the CLIMAP simulation with cooler tropics, the meridional temperature gradient is more similar to that in the present-day simulation, and the relative contributions from the source regions are in better agreement with those for the present-day climate. Still, though, the LGM gradient is a little higher than the present-day gradient due to a large cooling at high latitudes. The result is a slightly higher relative contribution of subtropical moisture to Antarctic precipitation. Note that in this LGM simulation, the evaporation itself is reduced at all latitudes.

Table 1 details the source contributions to total Antarctic precipitation. At the regional scale, when going from present-day to LGM conditions, the changes in the relative contributions are much larger than implied in the table. For example, in the Central Plateau, in the regions surrounding Vostok and Dome Concordia, the contribution of the Pacific source doubles under CLIMAP conditions at the expense of the high latitude ocean and Indian Ocean sources. This is probably due to (i) the increase in sea ice cover at high latitudes, and (ii) the warming of the tropical Pacific associated with a stronger meridional temperature gradient. In contrast, though it also shows a weakening of the high latitude ocean contribution, the "cool 
tropics" LGM simulation features a dramatic increase in the Indian Ocean contribution (up to $60 \%$ on annual average, and never less than $40 \%$ ). In Dronning Maud Land, with CLIMAP SSTs, the decrease of the high latitude moisture supply slightly enhances the Pacific and Atlantic proportions, by about $5 \%$ annually. The "cooler tropics" simulation decreases the Pacific contribution and increases that of the Atlantic to about $50 \%$ of the annual precipitation.

The annual weighted-average oceanic source temperatures, as defined in Subsection 3.1, are shown for both LGM simulations in Fig. 8 . Differences between the LGM and present-day $T$-ave values are also shown. As expected, the CLIMAP reconstruction increases the average source temperatures. The average of $T$-ave across the continent (weighted by precipitation amount) is $13.4^{\circ} \mathrm{C}$, which is $2.1^{\circ}$ higher than that for the present-day simulation. On the other hand, the "cooler tropics" LGM simulation shows slightly lower values of $T$-ave, with a continental average of $11.1^{\circ} \mathrm{C}$. These differences reflect the complex interplay between two separate factors controlling the changes in $T$-ave: the general decrease in SSTs, which tends to decrease $T$-ave, and the greater importance of more remote sources, which tends to increase it. For both LGM simulations, the highest increase in $T$-ave is seen at the strongest stationary low location, in Ross Sea and off the east coast (Fig. 4), secondly in Weddell Sea. In essence, this increase results from the replacement of cold high latitude moisture by warm subtropical moisture. These regions of highest increase of $T$ ave also show the warmest $T$-ave for LGM. It suggests that these cyclonic regions are especially able during glacial climates to transfer moisture from low to high latitudes through the Circumpolar Trough.

\section{Summary and discussion}

We have used an atmospheric general circulation model (AGCM) fitted with water tracer diagnostics to quantify the sources of Antarctic precipitation for both present-day and ice-age climates. Before summarizing the results, two important caveats must be underlined. First, this AGCM has a low horizontal resolution and was not built explicitly for polar studies. Our analysis could perhaps be improved through the use of a stretched-grid model (a "zoom" version of the AGCM) and by taking better account of the complex interactions known to exist between the atmosphere, sea ice, and ocean. Second, the realism of our tracer results can only be estimated indirectly through a comparison of the overall simulated hydrology with observed hydrological variables. Fortunately, the basic character of the simulated water cycle in the southern hemisphere and Antarctica is in many ways similar to that ascertained from data and numerical analyses (Jones and Simmonds, 1993; Bromwich et al., 1995), and it is deemed adequate for the firstorder analyses performed here.

For the present-day climate, most of the moisture that precipitates in Antarctica originates in the "subtropical" and "midlatitude" zones defined in Fig. 2. The relatively small contribution of equatorial and tropical moisture to this precipitation mirrors similar results found for Greenland with this model (Koster et al., 1986; Charles et al., 1994). When the last glacial maximum (LGM) climate is simulated with 2 different SST reconstructions, we find that the increased latitudinal temperature gradient and the increased sea ice extent result in a slightly higher contribution of low latitude moisture to Antarctic precipitation. This is particularly true in the CLIMAP simulation, which includes a warm intertropical zone (especially in the Pacific) that provides significant moisture. Cooling this intertropical zone in the second LGM simulation intensifies the cooling in high latitudes (by $1^{\circ}$ to $2^{\circ}$ ) and decreases slightly the meridional gradient, so the increase in the low latitude contribution is not quite as strong.

The breakdown of source contributions in Table 1 is reflected in the average oceanic source temperature ( $T$-ave) for annual Antarctic precipitation, computed to be $11.3^{\circ} \mathrm{C}$ for the presentday climate. An average source temperature can also be computed at each Antarctic grid cell. Fig. 8 shows that grid cells closer to the coast have a slightly higher tendency to derive moisture from colder (less remote) ocean surfaces. The figure also shows that the average source temperature can vary significantly with climate.

Our AGCM results show that in present-day and even more in LGM climates, a given region within Antarctica derives much of its moisture from the proximal ocean basin, especially if the 
region lies near the coast. In the eastern part of the Plateau, the Dome Concordia site is dominated by Indian Ocean moisture, with a weak seasonality in the Indian Ocean's contribution stemming from coastal and local (ice sheet) contributions. In the western part of the plateau, Dronning Maud Land receives moisture mainly from the Atlantic and the Pacific Oceans, with a contribution from high latitude ocean that varies seasonally with the presence of ice cover. Note that potential model errors increase toward the pole, so that results there must be considered with more caution.

The next step in our research is to examine how the seasonal and climatic variations in the contributions of the moisture sources relate to isotopic variations in ice core measurements. The AGCM simulations discussed above suggest some important clues and issues. In particular, the different values of $T$-ave computed for the two LGM simulations (Fig. 8) suggest that the nature of intertropical SSTs during the LGM must be firmly established if the interpretation of isotope paleodata is to account properly for changes in source temperature.

\section{Acknowledgements}

The authors are grateful to D. Rind for facilitating the use of the NASA/GISS AGCM; to R. Ruedy at GISS for technical assistance; to D. Bromwich and R. Cullather at Byrd Polar Research Center for providing their moisture transport estimates; and C. Genthon at the Laboratoire de Glaciologie et de Géophysique de l'Environnement for sharing the data of Dolgina and Petrova and for fruitful discussions. Simulations were run at the LSCE on an IBM Risc 6000 . This is LSCE contribution $n^{\circ} 300$.

\section{REFERENCES}

Berger, A. L. 1978. Long-term variations of daily insolation and Quaternary climatic changes. J. Atmos. Sci. 35, 2362-2367.

Blunier, T. et al. 1998. Asynchrony of Antarctic and Greenland climate change during the last glacial period. Nature 394, 739-743.

Broecker, W. S. 1997. Thermohaline circulation, the Achilles heel of our climate system : will man-made $\mathrm{CO} 2$ upset the current balance? Science $\mathbf{2 7 8}$, 1582-1588.

Bromwich, D. H. 1988. Snowfall in high southern latitudes. Rev. Geophys. 26, 149-168.

Bromwich, D. H., Robasky, F. M., Cullather, R. and Woert, M. L. V. 1995. The atmospheric hydrologic cycle over the Southern Ocean and Antarctica from operational numerical analyses. Mon. Wea. Rev. 123, 3518-3538.

Budd, W. F., Reid, P. A. and Minty, L. J. 1995. Antarctic moisture flux and net accumulation from global atmospheric analyses. Ann. Glaciol. 21, 149-156.

Charles, C. D., Rind, D., Jouzel, J., Koster, R. D. and Fairbanks, R. G. 1994. Glacial-interglacial changes in moisture sources for Greenland: influences on the ice core record of climate. Science 263, 508-511.

Ciais, P., White, J. W. C., Jouzel, J. and Petit, J.-R. 1995. The origin of present-day Antarctic precipitation from surface snow deuterium excess data. J. Geophys. Res. 100, 18917-18927.

CLIMAP, 1981. Seasonal reconstruction of the Earth's surface at the last glacial maximum. Technical Report, Geol. Soc. Am.
Cuffey, K. M., Clow, G. D., Alley, R. B., Stuiver, M., Waddington, E. D. and Saltus, R. W. 1995. Large Arctic temperature change at the Wisconsin-Holocene glacial transition. Science 270, 455-458.

Cullather, R. I., Bromwich, D. H. and Woert, M. L. V. 1996. Interannual variations in Antarctic precipitation related to El Niño-Southern oscillation. J. Geophys. Res. 101, 19 109-19118.

Delmotte, M. 1997. Enregistrements climatiques à Law Dome: variabilité, pour les périodes récentes et pour la déglaciation (in French). PhD thesis. Université Joseph Fourier - Grenoble I, France.

Dolgina, I. M. and Petrova, L. S. 1977. In: Handbook of Antarctic climate, vol. 2 (in Russian). Hydrological Institute, St Petersburg, Russia.

Ganopolski, A., Rahmstorf, S., Petoukhov, V. and Claussen, M. 1998. Simulation of modern and glacial climates with a coupled global model of intermediate complexity. Nature 391, 351-356.

Gates, W. L. 1992. AMIP: The Atmospheric Model Intercomparison Project. Bull. Amer. Meteor. Soc. 73, 1962-1970.

Genthon, C. 1994. Antarctic climate modeling with general circulation models of the atmosphere. J. Geophys. Res. 99, 12953-12961.

Giovinetto, M. B., Yamazaki, K., Wendler, G. and Bromwich, D. H. 1997. Atmospheric net transport of water vapor and latent heat across $60^{\circ} \mathrm{S}$. J. Geophys. Res. 102, 11 171-11 179.

Hansen, J. E., Russell, G., Rind, D., Stone, P., Lacis, A., Lebedeff, S., Ruedy, R. and Travis, L. 1983. Efficient

Tellus 52B (2000), 1 
three-dimensional global models for climate studies: Models I and II. Mon. Wea. Rev. 111, 609-662.

Hansen, J., Lacis, A., Rind, D., Russell, G., Stone, P., Fung, I., Ruedy, R. and Lerner, J. 1984. Climate sensitivity: analysis of feedback mechanisms. In: Climate processes and climate sensitivity (ed. J. E. Hansen and T. Takahashi). AGU, Whashington D. C., 130-163.

Johnsen, S. J., Dahl-Jensen, D., Dansgaard, W. and Gundestrup, N. 1995. Greenland palaeotemperatures derived from GRIP borehole temperature and ice core isotope profiles. Tellus 47B, 624-629.

Jones, D. A. and Simmonds, I. 1993. A climatology of Southern Hemisphere extratropical cyclones. Clim. Dyn. 9, 131-145.

Joussaume, S., Sadourny, R. and Vignal, C. 1986. Origin of precipitating water in a numerical simulation of the July climate. Ocean-Air Interactions 1, 43-56.

Jouzel, J. and Koster, R. D. 1996. A reconsideration of the initial conditions used for stable water isotope models. J. Geophys. Res. 101, 22 933-22 938.

Jouzel, J., Russell, G. L., Suozzo, R. J., Koster, R. D., White, J. W. C. and Broecker, W. S. 1987. Simulations of the $\mathrm{HDO}$ and $\mathrm{H}_{2}^{18} \mathrm{O}$ atmospheric cycles using the NASA GISS general circulation model: the seasonal cycle for present-day conditions. J. Geophys. Res. 92, 14739-14760.

Jouzel, J. et al. 1996. Climatic interpretation of the recently extended Vostok ice records. Clim. Dyn. 12, 513-521.

Jouzel, J. et al. 1997. Validity of the temperature reconstruction from water isotopes in ice cores. J. Geophys. Res. 102, 26 471-26487.

Kim, S.-J., Crowley, T. J. and Stössel, A. 1998. Local orbital forcing of Antarctic climate change during the Last Interglacial. Nature 280, 728-730.

Koster, R. D., Jouzel, J., Suozzo, R., Russell, G., Broecker, W., Rind, D. and Eagleson, P. 1986. Global sources of local precipitation as determined by the NASA/GISS GCM. Geophys. Res. Lett. 13, 121-124.

Koster, R. D., Eagleson, P. S. and Broecker, W. S. 1988 Tracer water transport and subgrid precipitation variation within atmospheric general circulation models. Tech. Report no. 317, Ralph M. Parsons Laboratory, Dept. of Civil Engineering, MIT, Cambridge, Massachusetts, USA

Koster, R. D., Jouzel, J., Suozzo, R. J. and Russell, G. L. 1992. Origin of July Antarctic precipitation and its influence on deuterium content: a GCM analysis. Clim. Dyn. 7, 195-203.

Krinner, G., Genthon, C. and Jouzel, J. 1997a. GCM analysis of local influences on ice core $\delta$ signals. Geophys. Res. Lett. 24, 2825-2828.

Krinner, G., Genthon, C., Li, Z.-X. and LeVan, P. 1997b. Studies of the Antarctic climate with a stretched-grid general circulation model. J. Geophys. Res. 102, 13731-13745.

Lorius, C., Merlivat, L., Jouzel, J. and Pourchet, M. 1979. A 30,000-yr isotope climatic record from Antarctic ice. Nature 280, 644-648.

Miller, J. R. and Russell, G. L. 1990. Oceanic freshwater transport during the last glacial maximum. Paleoceanography 5, 397-407.

Peixóto, J. P. and Oort, A. H. 1983. The atmospheric branch of the hydrological cycle and climate. In: Variations in the global water budget (eds. A. Street-Perrott, M. Beran and R. Ratcliffe). D. Reidel, 5-65, 1983.

Petit, J.-R., White, J. W. C., Young, N. W., Jouzel, J. and Korotkevich, Y. S. 1991. Deuterium excess in recent Antarctic snow. J. Geophys. Res. 96, 5113-5122.

Petit, J.-R. et al. 1997. Four climate cycles in Vostok ice core. Nature 387, 359-360.

Pinot, S., Ramstein, G., Harrison, S. P., Prentice, I. C., Guiot, J., Stute, M. and Joussaume, S. 1999. Tropical paleoclimates at the last glacial maximum: comparison of PMIP simulations and paleodata. Clim. Dyn. 15, 857-874.

Raynaud, D., Jouzel, J., Barnola, J.-M., Chappellaz, J., Delmas, R. J. and Lorius, C. 1993. The ice record of greenhouse gases. Science 259, 926-934.

Reynolds, R. W. 1988. A real time global sea-surface temperature analysis. J. Clim. 1, 75-86.

Rind, D. and Peteet, D. 1985. Terrestrial conditions at the last glacial maximum and CLIMAP sea-surface temperature estimates: are they consistent? Quat. Res. 24, 1-22.

Rind, D. 1987. Components of the Ice Age circulation. J. Geophys. Res. 92, 4241-4281.

Salamatin, A. N., Lipenkov, V. Y., Barkov, N. I., Jouzel, J., Petit, J.-R. and Raynaud, D. 1998. Ice-core age dating and palaeothermometer calibration based on isotope and temperature profiles from deep boreholes at Vostok station (East Antarctica). J. Geophys. Res. 103, 8963-8978.

Turner, J., Lachlan-Cope, T. A., Thomas, J. P. and Colwell, S. 1995. The synoptic origins of precipitation over the Antarctic Peninsula. Antarctic. Sci. 7, 327-337.

Tzeng, R.-Y., Bromwich, D. H., Parish, T. R. and Chen, B. 1994. NCAR CCM2 simulation of the modern Antarctic climate. J. Geophys. Res. 99, 23 131-23 148.

Warrick, R. A., Le Provost, C., Meier, M. F., Oerlemans, J. and Woodworth, P. L. 1996. Changes in the sea level. In: Climate change 1995: The science of climate change, IPCC (eds. J. T. Houghton, L. G. Meira Filho, B. A. Callander, N. Harris, A. Kattenberg and K. Maskell). Cambridge University Press, Cambridge UK, 359-405.

Yiou, F., Raisbeck, G., Bourles, D., Lorius, C. and Barkov, N. I. $1985 .{ }^{10} \mathrm{Be}$ in ice at Vostok, Antarctica, during the last climatic cycle. Nature 316, 616-617. 